Tropical Journal of Pharmaceutical Research January 2021; 20 (1): 105-111

ISSN: $1596-5996$ (print); 1596-9827 (electronic) (C) Pharmacotherapy Group, Faculty of Pharmacy, University of Benin, Benin City, 300001 Nigeria.

\title{
In vitro antiplasmodial, cytotoxic and antioxidant effects, and phytochemical constituents of eleven plants used in the traditional treatment of malaria in Akwa lbom State, Nigeria
}

\author{
Olorunfemi Abraham Eseyin ${ }^{1 *}$, Iweh Emmanuel Etim ${ }^{1}$, Emmanuel E Attih ${ }^{1}$, \\ Ekarika Johnson", Aniefiok Sunday Udobre', Aniekan Stephen Ebong ${ }^{1}$, Dennis \\ Zofou $^{2}$
}

${ }^{1}$ Department of Pharmaceutical and Medicinal Chemistry, Faculty of Pharmacy, University of Uyo, Uyo, Nigeria, ${ }^{2}$ Department of Biochemistry \& Pharmacology, University of Buea, Buea, Cameroon

*For correspondence: Email: olorunfemieseyin.pharm.lect@uniuyo.edu.ng; Tel: +234-8065161478

Sent for review: 9 June 2020

Revised accepted: 20 December 2020

\begin{abstract}
Purpose: To evaluate the antiplasmodial effects of eleven plants (Bombax buonopozense, Carica papaya, Anthocleista djalonensis, Milicia excelsa, Heterotis rotundifolia, Homalim letestui, Starchystarpheta cayennnensis, Ocimum gratissimum, Cleistopholis patens, Chromolaena odorata and Hippocratea africana) reportedly used in the treatment of malaria in Akwa Ibom State of Nigeria.

Methods: Phytochemical analysis was done by standard methods, while in vitro antiplasmodial evaluation was carried out using Plasmodium falciparum chloroquine-sensitive and chloroquineresistant strains using lactate dehydrogenase $(p L D H)$ assay. Cytotoxicity test was undertaken by MTT assay on LLC-MK2 cells and the concentration killing $50 \%$ of the cells $\left(C_{50}\right)$ was calculated. Antioxidant activity of the ethanol extract was evaluated by 2,2-diphenyl-1-picrylhydrazyl (DPPH) assay. Results: Milicia excelsa, Heterotis rotundifolia and Chromolaena odorata had moderate antiplasmodial activity. Ocimum gratissimum and Hippocratea africana were weakly active. Milicia excelsa showed a considerable level of cytotoxicity, while Bombax buonopozense exhibited moderate cytotoxicity. Bombax buonopozense (95.3 \%) and Ocimum gratissimum (92.0\%) exhibited high DPPH scavenging effect comparable to Vitamin C $(98.7 \%)$. There was a significant correlation $(p<0.05)$ between DPPH inhibition and the total phenolic contents of the eleven plants studied $\left(r^{2}=0.6616\right)$, between DPPH inhibition and flavonoids $\left(r^{2}=0.3553\right)$, between antiplasmodial activity and saponin content $\left(r^{2}=\right.$ $0.3992)$, and between the two antiplasmodial evaluation assay methods $\left(r^{2}=0.614\right)$.

Conclusion: The results of this work provide some justification for the use of Milicia excelsa, Heterotis rotundifolia, Chromolaena odorata, Ocimum gratissimum and Hippocratea africana in the treatment of malaria.
\end{abstract}

Keywords: Antiplasmodial, Antioxidant, Cytotoxicity, Phytochemicals, Antimalaria

\begin{abstract}
This is an Open Access article that uses a fund-ing model which does not charge readers or their institutions for access and distributed under the terms of the Creative Commons Attribution License (http://creativecommons.org/licenses/by/4.0) and the Budapest Open Access Initiative (http://www.budapestopenaccessinitiative.org/read), which permit unrestricted use, distribution, and reproduction in any medium, provided the original work is properly credited.

Tropical Journal of Pharmaceutical Research is indexed by Science Citation Index (SciSearch), Scopus, International Pharmaceutical Abstract, Chemical Abstracts, Embase, Index Copernicus, EBSCO, African Index Medicus, JournalSeek, Journal Citation Reports/Science Edition, Directory of Open Access Journals (DOAJ), African Journal Online, Bioline International, Open-J-Gate and Pharmacy Abstracts
\end{abstract}




\section{INTRODUCTION}

World estimate of infections and mortality from malaria annually is 500 million and 2.7 million, respectively. Ninety percent of these infections occur in Africa. Malaria causes about 3000 deaths daily and reduces economic growth by $1.3 \%$ per annum in endemic areas [1]. Malaria is the commonest disease in Nigeria, and accounts for a quarter of all cases of the disease in Africa [2]. The spread of Plasmodium falciparum resistance to antimalarial drugs has hampered malaria control program. Resistance to Artesunate-Amodiaquine combination therapy, the popular choice for malaria treatment in Nigeria and parts of Africa, has been reported [3]. This development has made the search for novel antimalaria drugs a necessity.

Plants are used as medicine by about $60 \%$ of the world's population [4]. Only $10 \%$ of the 250,000 species of plants in the world, have been screened for biological activity [4]. Many Nigerians use plants as remedies against malaria. In vitro antiplasmodial and/or in vivo antimalarial effects have been demonstrated in the extracts of 45 out of 51 plant species tested. The major proportion of malaria mortality occur in sub-Saharan African regions, it is necessary to encourage studies on plants from these regions.

This study was therefore undertaken to evaluate the antiplasmodial potential of eleven plants used in Akwa Ibom state, Nigeria, for the treatment of malaria. Evaluation of the antioxidant activity of the plants and quantification of some of their phytochemical components were also undertaken. Correlation among the evaluated parameters was determined.

\section{EXPERIMENTAL}

\section{Plant collection and extraction}

The plants were collected from Uyo metropolis, Akwa Ibom State, Nigeria, in June 2016. They were identified by Professor Magaret Bassey of the department of Botany and Ecological Studies, University of Uyo. The voucher number was assigned to each of the plants as shown in Table 1 and voucher specimens deposited in the herbarium of the Department of Pharmacognosy and Natural Medicine, University of Uyo, Nigeria. The plant materials were air dried and pulverized. Each of the powdered plant material $(200 \mathrm{~g})$ was macerated with $70 \%$ ethanol $(2 \mathrm{~L})$ for $72 \mathrm{~h}$. The extracts were filtered and concentrated using a rotary evaporator and dried in a desiccator with silica gel.

\section{Quantification of phytochemicals}

Determination of Alkaloids was performed according to the method of Harborne [5]. Estimation of saponins was done according to the method of Obdoni and Ochuko [6]. Total phenolic content was determined following the method of Singleton and Rossi [7]. Flavonoid content was evaluated by the method of Ahn et al [8]. The quantitative content of carotenoids and lycopene in the leafy extract is determined using the colorimetric method described by Nagata and Yamashita [9].

\section{In vitro antiplasmodial effect}

Stock solutions were prepared by dissolving 2 mg dry crude extracts in $200 \mu \mathrm{L}$ dimethyl sulfoxide (DMSO) from Sigma (MO, USA) and then diluting with complete culture medium to make $2000 \mu \mathrm{g} / \mathrm{mL}$. All solutions were sterilized by passing through $0.22 \mu \mathrm{m}$ syringe-adapted filters (Corning ${ }^{\circledR}, \mathrm{NY}$, USA) and stored at $4^{\circ} \mathrm{C}$ until use. Plasmodium falciparum Chloroquinesensitive (CS2) and Plasmodium falciparum Chloroquine-resistant (W2mef) strains were cultured in vitro [10] with modifications. Parasites were grown in uninfected $\mathrm{O}+$ human red blood cells as host cells and maintained in complete malaria culture medium composed of RPMI-1640 medium supplemented with $\mathrm{NaHCO}_{3}(2 \mathrm{mg} / \mathrm{mL})$, hypoxanthine $(10 \mu \mathrm{g} / \mathrm{mL})$, glucose $(2 \mathrm{mg} / \mathrm{mL})$, albumax II (1\%) and gentamicin $(10 \mu \mathrm{g} / \mathrm{mL})$. The parasite cultures were incubated in $\mathrm{CO}_{2}(5 \%)$, $\mathrm{O}_{2}(5 \%)$ and $\mathrm{N}_{2}(90 \%)$ at $37^{\circ} \mathrm{C}$. All the solutions were sterilized with $0.22 \mu \mathrm{m}$ syringe-adapted filters (Corning ${ }^{\circledR}, \quad N Y, \quad$ USA). In vitro antiplasmodial activity of the extracts were evaluated using parasite lactate dehydrogenase (pLDH) assay.

Different concentrations of extracts were incubated with non-synchronized $1 \%$ parasitized red blood cells (pRBCs) at $2 \%$ hematocrit (hct) in 96 well microtiter plates (Costar ${ }^{\circledR}$, Corning, NY, USA) . Quinine was used as positive control. The test was performed in triplicate for each concentration. Wells with only $1 \%$ pRBCs at $2 \%$ HCT without extract, were included as negative controls (100\% parasite growth). Wells without pRBCs but with red blood cells only at $2 \%$ HCT served as blank controls. Parasites cultures with extracts were maintained for $48 \mathrm{~h}$ at $37{ }^{\circ} \mathrm{C}$ in $\mathrm{CO}_{2}(5 \%), \mathrm{O}_{2}(5 \%)$, and $\mathrm{N}_{2}(90 \%)$. After $48 \mathrm{~h}$ of incubation, the plates were frozen overnight at $20{ }^{\circ} \mathrm{C}$ and antiplasmodial activity was evaluated using pLDH assay performed as described previously. The concentration of the extracts that inhibited fifty percent of the parasite growth $\left(\mathrm{IC}_{50}\right)$ 
was determined by GraphPad Prism, version 7.03

\section{In vitro cytotoxicity test}

Stock solutions were prepared by dissolving 1 mg dry crude extracts in $200 \mu \mathrm{L}$ DMSO (Sigma $\mathrm{MO}$, USA) and then diluting with cell culture medium to make $100 \mu \mathrm{g} / \mathrm{mL}$. All the solutions were sterilized by using $0.22 \mu \mathrm{m}$ syringe-adapted filters (Corning ${ }^{\circledR}, N Y$, USA) and kept at $4{ }^{\circ} \mathrm{C}$ until use. Cytotoxicity was determined on LLC-MK2 monkey kidney epithelial cells. The cells were grown in DMEM culture medium which was supplemented with $10 \%$ fecal bovine serum (FBS, Life Technologies) and $1 \%$ penicillin/Streptomycin. Trypsinated cells were distributed in 96 well microtiter plates at a density of 10,000 cells/well in a volume of $100 \mu \mathrm{L}$ per well and incubated for $48 \mathrm{~h}$ before adding the extracts. After $48 \mathrm{~h}$, the medium was removed completely from each well, and $100 \mu \mathrm{L}$ of fresh culture medium was then added. Thereafter, 100 $\mu \mathrm{L}$ of crude extract $(2000 \mu \mathrm{g} / \mathrm{mL})$ was added in row $\mathrm{H}$ and then serially diluted to row $\mathrm{B}$ to give concentrations ranging from $1000-15.6 \mu \mathrm{g} / \mathrm{mL}$. Cells in row $A$ served as controls without drug (100\% growth). The cells with or without extracts were incubated in $\mathrm{CO}_{2}(5 \%), \mathrm{O}_{2}(5 \%), \mathrm{N}_{2}(90$ $\%$ ) incubator at $37{ }^{\circ} \mathrm{C}$ for $72 \mathrm{~h}$ before determining their viability. Each concentration was determined in triplicate. Cell viability was determined using MTT assay and the cytotoxic activity was determined according to the previous studies [11]. The percentage viability and percentage mortality were calculated from the absorbance values using Microsoft Excel. The mean results of the percentage mortality were plotted against the logarithms of concentrations using HN-NonLin V1.1 (2002) and GraphPath Prism software. Regression equations obtained from the graphs were used to calculate cytotoxic concentration fifty $\left(\mathrm{CC}_{50}\right)$, which is the concentration that killed $50 \%$ of the cells.

\section{Evaluation of DPPH-radical scavenging activity}

The DPPH antioxidant capacity of the extracts, and vitamin $\mathrm{C}$ were evaluated by the method of Enujiugha [12]. A solution of DPPH $(0.1 \mathrm{~mm})$ was prepared in methanol and $0.5 \mathrm{ml}$ of this solution added to $1.5 \mathrm{ml}$ of test sample in ethanol at different concentrations $(50-250 \mathrm{mg} / \mathrm{ml})$. The solutions were vortexed thoroughly and incubated in the dark for about 30 minutes. The absorbance was measured at $517 \mathrm{~nm}$ against blank samples. Inhibition $(\mathrm{H})$ of free radical $\mathrm{DPPH}$ was calculated as in Eq 1.

$H(\%)=\{(\mathrm{Ab}-\mathrm{As}) / \mathrm{Ab}\} 100 \ldots \ldots .(1)$

where $A b$ and As are the absorbance of blank and test samples, respectively.

\section{Statistical analysis}

Data are expressed as mean \pm standard error of the mean (SEM) and analyzed using one-way analysis of variance (ANOVA) with the aid of GraphPad Prism software, version 7.03 for Windows, GraphPad Software, San Diego, California USA). Values of $p<0.05$ were considered significant.

\section{RESULTS}

The names, voucher numbers, and parts of the plants studied are shown in Table 1.

\section{In vitro antiplasmodial property}

The antiplasmodial property of the extracts on two reference laboratory strains of $P$. falciparum is presented in Table 2. Considering significant activity in terms of $\mathrm{IC}_{50}$ below 10 on at least two strains, five out of the eleven tested extracts can be classified as having promising activity.

Table 1: Plants studied and their voucher numbers

\begin{tabular}{lll}
\hline Plant name (family) & Part & Voucher no. \\
\hline Anthocleista djalonensis (Gentianaceae) & Roots & UUPH45a \\
Bombax buonopozense (Malvaceae) & Leaves & UUPH31a \\
Carica papaya (Caricaceae) & Leaves & UUPH18a \\
Chromolaena odorata (Asteraceae) & leaves & UUPH10c \\
Cleistopholis patens (Annonaceae) & Root & UUPH4f \\
Heterotis rotundifolia (Melastomataceae) & leaves & UUPH48a \\
Hippocratea africana (Celastraceae) & Root & UUPH34a \\
Homalim letestui (Flacourtiaceae) & Stem bark & UUPHA69i \\
Milicia excelsa (Moraceae) & Stem bark & UUPH50b \\
Ocimum gratissimum (Labiatea) & leaves & UUPH38a \\
Starchystarpheta cayennnensis (Verbenaceae) & Leaf & UUPH78c \\
\hline
\end{tabular}


Table 2: Antiplasmodial activity $\left(\mathrm{IC}_{50}\right)$ of the extracts on chloroquine-sensitive Plasmodium falciparum (CS2) and Plasmodium falciparum Chloroquine-resistant (W2mef) strains

\begin{tabular}{lccl}
\hline Plant & IC $_{50}$ on CS2 & $\begin{array}{c}\mathbf{I C}_{50} \text { on W2 } \\
(\boldsymbol{\mu g} / \mathbf{m L})\end{array}$ & Observation \\
\hline Anthocleista djalonensis & $3.55 \pm 0.95$ & $>1000$ & Inactive \\
Bombax buonopozense & $2.94 \pm 0.03$ & $125.23 \pm 8.23$ & Inactive \\
Carica papaya & $>1000$ & $>1000$ & Inactive \\
Chromolaena odorata & $3.89 \pm 0.92$ & $7.12 \pm 4.88$ & Moderately active \\
Cleistopholis patens & $21.43 \pm 2.45$ & $14.68 \pm 1.02$ & Inactive \\
Heterotis rotundifolia & $4.63 \pm 0.02$ & $7.80 \pm 0.73$ & Moderately active \\
Hippocratea africana & $15.66 \pm 2.92$ & $6.95 \pm 0.09$ & Weakly active \\
Homalim letestui & $>1000$ & $222.20 \pm 2.24$ & Inactive \\
Milicia excelsa & $6.43 \pm 1.27$ & $3.88 \pm 2.49$ & Moderately active \\
Ocimum gratissimum & $23.23 \pm 3.35$ & $4.17 \pm 0.23$ & Weakly active \\
Starchystarpheta cayennnensis & $>1000$ & $>1000$ & Inactive \\
Quinine & $0.09 \pm 0.005$ & $0.12 .50 \pm 0.03$ & \\
\hline
\end{tabular}

$\mathrm{IC}_{50}<0.03$ : Highly active $; 0.03<\mathrm{IC}_{50}<2.5$ : active $; 2.5<\mathrm{IC}_{50}<10$ : moderately - weakly active; $\mathrm{IC}_{50}>10$ : inactive [15]. Mean and SEM values were generated from three replicates of each assay

\section{Cytotoxicity profiles of the extracts}

Table 3 presents the cytotoxic concentration $50 \%$ $\left(\mathrm{CC}_{50}\right)$ for the extracts on the LLC-MK2 Monkey kidney epithelial cell line. From this data, two out of the 11 extracts exhibited moderate toxicity against LLC-MK2 cell line, namely Milicia excelsa and Bombax buonopozense, with $\mathrm{CC}_{50}$ between 10 and $30 \mu \mathrm{g} / \mathrm{mL}$.

\section{Antioxidant activity of the extracts}

Results of DPPH scavenging property of the plant extracts are shown in Figure 1.

\section{Phytochemical profile of the extracts}

The composition of phytochemical constituents of the plants are as shown in Table 4.

The results of the correlation analysis are shown in Table 5

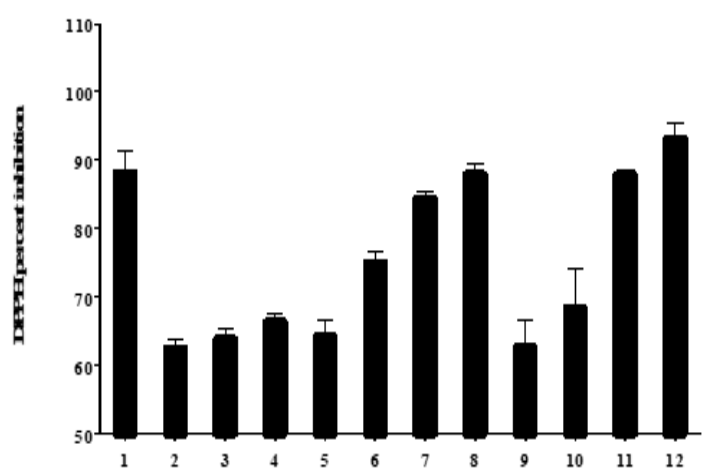

Figure 1: DPPH percent inhibition of the plants. 1. Bombax buonopozense, 2. Carica papaya, 3. Anthocleista djalonensis, 4. Milicia excelsa, 5. Heterotis rotundifolia, 6. Homalim letestui, 7. Starchystarpheta cayennnensis, 8. Ocimum gratissimum, 9. Cleistopholis patens, 10. Chromolaena odorata, 11. Hippocratea africana, 12. Vitamin C

Table 3: Cytotoxicity $\left(\mathrm{CC}_{50}\right)$ of the plant extracts

\begin{tabular}{|c|c|c|}
\hline Plant & $\begin{array}{c}\text { CC }_{50} \text { on LLC-MK2 } \\
(\mu \mathrm{g} / \mathrm{mL})\end{array}$ & Observations \\
\hline Anthocleista djalonensis & $316.83 \pm 1.70$ & Non-cytotoxic \\
\hline Bombax buonopozense & $22.12 \pm 6.38$ & Moderately cytotoxic \\
\hline Carica papaya & $170.54 \pm 6.96$ & Non-cytotoxic \\
\hline Chromolaena odorata & $35.17 \pm 3.79$ & Non-cytotoxic \\
\hline Cleistopholis patens & $415.63 \pm 6.82$ & Non-cytotoxic \\
\hline Heterotis rotundifolia & $542.63 \pm 15.45$ & Non-cytotoxic \\
\hline Hippocratea africana & $48.60 \pm 4.11$ & Non-cytotoxic \\
\hline Homalim letestui & $52.41 \pm 10.15$ & Non-cytotoxic \\
\hline Milicia excelsa & $10.95 \pm 0.55$ & Cytotoxic \\
\hline Ocimum gratissimum & $486.38 \pm 4.57$ & Non-cytotoxic \\
\hline Starchystarpheta cayennnensis & $438.97 \pm 13.20$ & Non-cytotoxic \\
\hline Gleevec (Imatinib) & & Weakly cytotoxic \\
\hline
\end{tabular}


Table 4: Phytochemical composition of the plants

\begin{tabular}{|c|c|c|c|c|c|c|}
\hline Plant & $\begin{array}{l}\text { Phenolics } \\
\text { (mg/mL) }\end{array}$ & $\begin{array}{l}\text { Flavonoids } \\
\text { (mg/mL) }\end{array}$ & $\begin{array}{c}\beta \text {-Carotene } \\
\text { (mg/100 mL) }\end{array}$ & $\begin{array}{c}\text { Lycopene } \\
\text { (mg/100 mL) }\end{array}$ & $\begin{array}{c}\text { Saponins } \\
(\% \mathrm{w} / \mathrm{w})\end{array}$ & $\begin{array}{l}\text { Alkaloids } \\
(\% \mathrm{w} / \mathrm{w})\end{array}$ \\
\hline Anthocleista djalonensis & $0.0508 \pm 0.01$ & $0.0031 \pm 0.000$ & $0.0436 \pm 0.00$ & $0.0129 \pm 0.002$ & $0.26 \pm 0.01$ & $0.44 \pm 0.01$ \\
\hline Bombax buonopozense & $0.2912 \pm 0.03$ & $0.0058 \pm 0.000$ & $0.4199 \pm 0.01$ & $0.0895 \pm 0.005$ & $0.10 \pm 0.01$ & $0.32 \pm 0.01$ \\
\hline Carica papaya & $0.0881 \pm 0.01$ & $0.0309 \pm 0.004$ & $0.8220 \pm 0.03$ & $0.1045 \pm 0.006$ & $0.94 \pm 0.01$ & $4.98 \pm 0.08$ \\
\hline Chromolaena odorata & $0.0858 \pm 0.01$ & $0.0198 \pm 0.004$ & $7.4955 \pm 0.09$ & $0.8723 \pm 0.007$ & $0.32 \pm 0.01$ & $3.32 \pm 0.05$ \\
\hline Cleistopholis patens & $0.1715 \pm 0.01$ & $0.0115 \pm 0.001$ & $0.4666 \pm 0.03$ & $0.0893 \pm 0.002$ & $0.44 \pm 0.01$ & $3.86 \pm 0.03$ \\
\hline Heterotis rotundifolia & $0.1611 \pm 0.02$ & $0.0152 \pm 0.002$ & $2.9937 \pm 0.06$ & $0.1978 \pm 0.006$ & $0.22 \pm 0.01$ & $2.48 \pm 0.02$ \\
\hline Hippocratea africana & $0.3973 \pm 0.02$ & $0.1938 \pm 0.006$ & $0.3721 \pm 0.03$ & $0.0094 \pm 0.000$ & $0.84 \pm 0.01$ & $2.42 \pm 0.02$ \\
\hline Homalim letestui & $0.1662 \pm 0.03$ & $0.0103 \pm 0.001$ & $0.0343 \pm 0.00$ & $0.0063 \pm 0.000$ & $0.32 \pm 0.01$ & $0.42 \pm 0.01$ \\
\hline Milicia excelsa & $0.1270 \pm 0.03$ & $0.0109 \pm 0.001$ & $0.0436 \pm 0.00$ & $0.0092 \pm 0.000$ & $0.24 \pm 0.01$ & $1.38 \pm 0.03$ \\
\hline Ocimum gratissimum & $0.6800 \pm 0.03$ & $0.0796 \pm 0.001$ & $0.9096 \pm 0.04$ & $0.0563 \pm 0.002$ & $0.44 \pm 0.01$ & $4.72 \pm 0.09$ \\
\hline $\begin{array}{l}\text { Starchystarpheta } \\
\text { cayennnensis }\end{array}$ & $0.3666 \pm 0.03$ & $0.0675 \pm 0.002$ & $0.6779 \pm 0.01$ & $0.0522 \pm 0.004$ & $1.28 \pm 0.07$ & $3.26 \pm 0.03$ \\
\hline
\end{tabular}

Table 5: Correlation $\left(r^{2}\right)$ between phytochemicals and activities (antiplasmodial, cytotoxicity and antioxidants)

\begin{tabular}{lcccccc}
\hline Activity & Phenolics & Flavonoids & $\begin{array}{c}\boldsymbol{\beta} \text {-Carotene } \\
(\mathbf{m g} / \mathbf{1 0 0} \mathbf{~ m l})\end{array}$ & $\begin{array}{c}\text { Lycopene } \\
(\mathbf{m g} / \mathbf{1 0 0} \mathbf{~ m l})\end{array}$ & $\begin{array}{c}\text { Saponins } \\
(\mathbf{\%})\end{array}$ & $\begin{array}{c}\text { Alkaloids } \\
(\%)\end{array}$ \\
\hline Antiplasmodial & 0.004119 & 0.008835 & 0.07506 & 0.07574 & $0.3992^{*}$ & 0.03498 \\
cytotoxicity & 0.1087 & 0.01321 & 0.06315 & 0.09560 & 0.04415 & 0.2226 \\
$\begin{array}{l}\text { DPPH inhibitory } \\
\text { activity }\end{array}$ & $0.6616^{*}$ & $0.3553^{*}$ & 0.004784 & 0.01254 & 0.05372 & 0.007468 \\
\hline
\end{tabular}

${ }^{\star} P<0.05$ (two-tailed)

\section{DISCUSSION}

Stembark extract and root of Milicia excelsa are used to treat fever and malaria in the southern part of Nigeria [15]. The result of this study showed that Milicia excelsa possessed in vitro antiplasmodial activity, thereby justifying the ethnobotanical use of the plant extract for the treatment of malaria. The results of this study also showed that the stem bark of the plant is cytotoxic $\left(\mathrm{CC}_{50}\right.$ on LLC-MK2 is $10.95 \pm 0.55$ $\mu \mathrm{g} / \mathrm{mL}$ ). The root extract of the plant has earlier been reported to be cytotoxic. This plant should therefore be used with caution because of its cytotoxicity.

The leaf of Carica papaya is reportedly used in ethnomedicine for malaria treatment, but the result of this study does not confirm this claim.

The methanol leaf extract of $B$. buonopozense has been reported to possesses significant antiplasmodial activity thus confirming its traditional use in malarial therapy [16]. But the ethanol leaf extract used in this study did not show any antiplasmodial activity. However, the antiplasmodial property of plant extracts has been reported to vary with the solvent used for extraction and this may account for the differences between the reported antiplasmodial property of the plant and the results obtained in this study.
Anthocleista djalonensis leaf extract reportedly exhibited a significant antiplasmodial activity [17]. However, in this study the root extract was found to be inactive. This shows that, unlike the leaf and stem bark, the root extract of the plant may not have any beneficial antiplasmodial activity. This study shows that the ethanol leaf extract of Heterotis rotundifolia plant possesses moderate antiplasmodial activity. There is scanty information in literature on the antiplasmodial activity of this plant.

From the results of this study, the stem bark of Homalim letestui, did not possess antiplasmodial activity. This result is in tandem with earlier report [18]. However, in vivo study reported the significant antiplasmodial activity of the root [23]. Therefore, the root, rather than the stem bark and leaf, of the plant could be exploited further for malaria treatment.

The results of this study showed of Stachytarpheta cayennensis leaves do not possess antiplasmodial activity. This result is at variance with the report that the leaf extract exhibited significant blood schizonticidal property comparable to chloroquine [19].

In this study ethanol extract of the leaf of Ocimum gratissimum possessed weak antiplasmodial, activity. This result agrees with the report of the antiplasmodial activity of the leaves on $P$. falciparum F32. The results of this work showed that the root extract of Cleistopholis 
patens possesses no antiplasmodial effect and is non-cytotoxic. However, the stem bark is reportedly used in the treatment of malaria in Cameroon [20].

Leaf extract of Chromolaena odorata according to this study show moderate antiplasmodial activity. This agrees with the reported antiplasmodial activity of the plant [21]. Results of the antiplasmodial activity of the root extract of Hippocratea africana show that the root extract is moderately active, in agreement with the reported activity of the ethanol root extract of the plant.

There was a significant correlation $\left(r^{2}=0.6616, p\right.$ $<0.05$ ) between the DPPH percent inhibition and total phenolic contents of the eleven plant extracts tested in this study. The correlation between DPPH inhibitory activity and flavonoids was also significant $\left(r^{2}=0.3553, p<0.05\right)$. This is expected since phenolics in general and flavonoids in particular are well known to be responsible for the antioxidant properties of plants.

Similarly, the correlation between antiplasmodial activity and saponin content of the plant extracts was significant $\left(r^{2}=0.3992, p<0.05\right)$. This result show that the antiplasmodial components of these plants may be reasonably attributable to their saponin contents. Many saponins have been known to exhibit antiplasmodial properties. There was no significant correlation between the antiplasmodial and antioxidant effects of the plants. The two antiplasmodial evaluation assays using Plasmodium falciparum Chloroquinesensitive (CS2) and Plasmodium falciparum Chloroquine-resistant (W2mef) strains) had a significant correlation of 0.614 .

\section{CONCLUSION}

The results of this study provide some support for the use of Milicia excelsa, Heterotis rotundifolia, Chromolaena odorata, Ocimum gratissimum and Hippocratea africana in malaria treatment. Milicia excelsa and Bombax buonopozense should be used with caution because of their cytotoxicity. Bombax buonopozense and Ocimum gratissimum show high DPPH inhibitory activity comparable to that of vitamin $\mathrm{C}$.

\section{DECLARATIONS}

\section{Acknowledgement}

The authors are grateful to International Foundation for Science (IFS) for supporting this work through a collaborative research grant $(\mathrm{J}$ 5019 - 2) awarded to Olorunfemi Eseyin. We are also grateful to Mr Etefia Udofia who assisted in plant collection and Prof Margaret Bassey for plant identification.

\section{Conflict of interest}

No conflict of interest is associated with this work.

\section{Contribution of authors}

We declare that this work was done by the authors named in this article and all liabilities pertaining to claims relating to the content of this article will be borne by the authors.

\section{Open Access}

This is an Open Access article that uses a funding model which does not charge readers or their institutions for access and distributed under the terms of the Creative Commons Attribution License (http://creativecommons.org/licenses/by/ 4.0) and the Budapest Open Access Initiative (http://www.budapestopenaccessinitiative.org/rea d), which permit unrestricted use, distribution, and reproduction in any medium, provided the original work is properly credited.

\section{REFERENCES}

1. WHO. World Malaria Report 2008. World Health Organization, Geneva; 2008; pp 7-15, 99-101.

2. Federal Ministry of Health. National Antimalarial Treatment Policy. Federal Ministry of Health, Abuja, Nigeria; 2004.

3. Arjen $M D$, François $N$, Poravuth $Y$, Debashish Das, Aung $P P$, Joel $T$, Khin ML, Frederic A, Warunee $H$, Sue $J L$, Pascal $R$ et al. Artemisinin Resistance in Plasmodium falciparum Malaria. N Engl J Med 2009; 361(5): 455467

4. Farnsworth NR. Ethnobotany and the Search for New Drugs, Wiley; 1994

5. Harborne JB. Phytochemical methods: a guide to modern techniques of plant analysis. 2nd ed. London: Chapman and Hall; 1998.

6. Obdoni BO, Ochuko PO. Phytochemical studies and comparative efficacy of the crude extracts of some Homostatic plants in Edo and Delta States of Nigeria. Glob J Pure Appl Sci 2001; 8(2): 203-208.

7. Singleton VL, Rossi JR. Colorimetry of total phenols with phosphomolybdic-phosphotungstic acid reagents. Ame J Enol Viticult 1965; 16: 144-158.

8. Ahn MR, Kumazawa S, Usui Y, Nakamura J, Matsuka M, Zhu F, Nakayama T. Antioxidant activity and 
constituents of propolis collected in various areas of China. Fd Chem 2007; 101: 1383-1392.

9. Nagata M, Yamashita I. Simple method for simultaneous determination of chlorophyll and carotenoids in tomato fruit. Japan Soc Fd Sci Technol 1992; 39 (10): 925-928.

10. Trager $W$, Jensen JB. Human malaria parasites in continuous culture. Sci 1976; 193: 673-675.

11. Nondo RSO, Moshi MJ, Erasto P, Zofou D, Njouendou AJ, Wanji S. Evaluation of the cytotoxic activity of extracts from medicinal plants used for the treatment of malaria in Kagera and Lindi regions, Tanzania. J Appl Pharm Sci 2015; 5 (04): 007-012.

12. Enujiugha VN, Talabi JY, Malomo SA, Olagunji AI. DPPH radical scavenging capacity of phenolic extracts from African yam beans (Sphenostylis stenocarpa). J Fd Nutr Sci 2012; 3: 7-13.

13. Rasoanaivo $P$, Deharo $E$, Ratsimamanga-Urverg $S$, Frappier F. Guidelines for the Nonclinical Evaluation of the Efficacy of Traditional Antimalarials. In Willcox, $M$, Bodeker G, Titanji VPK, Zofou, D, Ngemenya, MN, 2008. The Antimalarial Potential of Medicinal Plants Used for The Treatment of Malaria in Cameroonian Folk Medicine. Afr J Trad CAM 2004; 5 (3):302 - 321.

14. Malebo HM, Tanja W, Cal M, Swaleh SAM, Omolo MO, Hassanali A. Antiplasmodial, anti-trypanosomal, antileishmanial and cytotoxicity activity of selected Tanzanian medicinal plants. Tanzania $\mathrm{J}$ Health Res 2009; 11(4): 226-234.
15. Areola JO, Omisore NO, Babalola OO. Antiplasmodial activity of stem-bark extract of Milicia excelsa (welw.) C.C.Berg against rodent malaria parasites (Plasmodium berghei) in mice. Ife J Sci 2016; 18 (4): 905-911.

16. Akuodor GC, Mbah CC, Megwas UA, Ikoro NC, Akpan $J L$, Okwuosa BO, Osunkwo UA. In vivo antimalarial activity of methanol leaf extract of Bombax buonopozense in mice infected with Plasmodium berghei. Int J Bio Chem Sci 2011; 15(5): 1790-1796.

17. Bassey AS, Okokon JE, Etim El, Umoh FU, Bassey E. Evaluation of the in vivo antimalarial activity of ethanolic leaf and stembark extracts of Anthocleista djalonensis. Indian J Pharmacol 2009; 41(6): 258-261.

18. Okokon JE, Okokon PJ, Sahal D. In vitro antiplasmodial activity of some medicinal plants from Nigeria. Int J Herbal Med 2017; 5(5): 102-109.

19. Okokon JE, Ettebong E, Antia BS. In vivo antimalarial activity of ethanolic leaf extract of Stachytarpheta cayennensis. Indian J Pharmacol 2008; 40(3): 111-113.

20. Chinsembu KC. Plants as antimalarial agents in SubSaharan Africa. Acta Trop 2015; 152: 32-48.

21. Chenniappan K, Kadarkarai $M$. In vitro antimalarial activity of traditionally used Western Ghats plants from India and their interactions with chloroquine against chloroquine-resistant Plasmodium falciparum. Parasitol Res 2010; 107: 1351-1364. 